\title{
Comparative Analgesic Effect of Traditional Formulation Shuntyadi Yoga Lepa and Its Neo Formulation as Balm on Shirashula
}

\author{
Research Article
}

\section{Shreevalli P1, Vinaykumar R Kadibagil2*}

1. UG Scholar. 2. Professor \& Head, Department of Rasashastra \& Bhaishajya kalpana

Sri Dharmasthala Manjunateshwara College of Ayurveda and Hospital, Hassan-573201.

\begin{abstract}
Background: Chikista is mainly of two types i.e., antaraparmarjana and bahiramarimrjana. For relief of sthanika lakshana, immediate sthanika chikista is required. Lepa kalpana is one type of barimarimarjana chikista. Lepa pacifies the provoked local dosha by prahladana, shodhana, sopha harana. Shirah is the "uttamanga" of all the anga of the sharira and it is the abode (ashraya) of the prana and indriya. Charaka has described five types of shiroroga, whereas Sushruta, Bhavamishra and Yogaratnakara have classified eleven types of shiroroga. Shirashoola is also mentioned as synonym of shiroroga. Methods:Shuntyadi yoga is traditionally practised medicine which was used for treatment of shirashula. With the intention of forwarding the traditional knowledge and patient compliance the shuntyadi yoga was modified into balm form. The ingredients of shuntyadi yoga are shunti, haridra, maricha, lashuna and for the balm form additional ingredients like menthol, methyl salicylate, camphor was added. Ghanasara of drugs was prepared and used for preparation of vati and balm. Results:All the ingredients of formulation have reference of shulahara property so when they are formulated together because of synergetic effect their efficacy will be potentiated. Both formulations were administered for 15 patients each and the result was analysed. Conclusion:The results shown that both forms were effective in shoolahara property. Comparing the patient's feedback, it can be concluded that balm formulation was beneficial considering organoleptic characters and patient compliance. So, shuntyadi yoga can be prepared in balm form which will continue the usage of traditional practice.
\end{abstract}

Key Words: Shuntyadi yoga, Lepa, Balm, Shirashula, Shulahara, Bahyaparimarjana chikista.

\section{Introduction}

Chikista is mainly of two types i.e., antaraparmarjana and bahiramarimrjana. For relief of sthanika lakshana, immediate sthanika chikista is required. Lepa kalpana is one type of barimarimarjana chikista. Description of lepa kalpana is scattered in the classical books. Advantages of topical applications are direct application at the site of action, easy removal if any aggravation exists and easy manner of application. Synonyms of lepa are lipta, lepa, lepana and alepa. Lepa kalpana can be prepared by pounding wet drugs or adding water to the dry drug in the form of paste which will be used for external application. From pharmaceutical point of view, lepa kalpana is a form of kalka kalpana(1).

The purpose for which it is used decides its nomenclature. Acharya while explaining the efficiency of lepa, has cited the version like "As the fire gets extinguished immediately with the action of water; in

\section{* Corresponding Author:}

Vinaykumar R Kadibagil

Professor \& HOD,

Department of Rasashastra \& Bhaishajya kalpana,

Sri Dharmasthala Manjunateshwara College of

Ayurveda and Hospital, Hassan-573201 India.

Email Id: drvinaykadibagil@gmail.com similar manner, lepa pacifies the provoked local dosha by prahladana, shodhana, sophaharana".

The Indian mythology emphasizes the prime place of shirah in the body as said by Lord Krishna himself the base of the man is head while whole body is just like its branch.

Acharya has divided body anatomically into six parts viz. shirah, antaradhi, two bahu and two sakthi placing the "shirah" at the first place. Thus, ayurvedic seers unanimously place "shirah" at first place among all the body parts. While defining shirah, it was explained that shirah is the "uttamanga" of all the anga of the sharira and it is the abode (ashraya) of the prana and indriya.

In classical books we find five and eleven types of shiroroga and mentioned shiroruk as separate disease among eighty types of vata vyadhi. In the classical texts, the word shiroroga has been used to denote painful condition of head, that's why other diseases of head such as khalitya, arunshika, etc. are not included in shiroroga. In classics, general line of treatment for shirashula has been described as swedana, nasya, dhumapana, virechana, lepa, vamana, langhana, shirobasti, raktamokshana, agnikarma, upanaha, purana ghrita and shashtikashali $(2,3,4)$.

Shuntyadi yoga is a folklore formulation in practise being used by generations for treatment of shirashula. The ingredients of the formulation are easily available in kitchen and can be prepared easily. An attempt was made to bring the knowledge of our 
Shreevalli P et.al., Comparative Analgesic Effect of Traditional Formulation Shuntyadi Yoga Lepa in Shirashula

ancestors in to easily acceptable form and so that it will be carried to next generation. But the formulation practiced was in crude form i.e., pellet which should be warmed before application and was not patient compliance. Here an effort was made to modify it into neo formulation so that the essence of the traditional medicine will also be preserved.

\section{Materials and Methods}

Shuntyadi yoga was prepared in two different formulations i.e., pellets and balm in department of Rasashastra and Bhaishajya Kalpana, SDM College of Ayurveda and Hospital, Hassan.

\section{Drug collection and authentication}

Drugs required were collected from local vendor. The herbal drugs were authenticated from the experts of Dravya Guna. Table 1 gives the list of ingredients and quantity taken. Ingredients were pounded separately and fine powder of these drugs except lashuna was collected by filtering through the clean cloth. Fine powder of all the drugs and paste of lashuna were triturated with addition of water till subhavita lakshana were obtained. Fine paste of mixture was converted into pellets of weighing $3 \mathrm{~g}$ each and total 63 pellets were obtained which were stored in airtight bottles.

\begin{tabular}{|c|c|c|c|c|}
\hline $\begin{array}{l}\text { Sl } \\
\text { no }\end{array}$ & $\begin{array}{l}\text { Name of } \\
\text { the drug }\end{array}$ & $\begin{array}{l}\text { Latin/ } \\
\text { English } \\
\text { name }\end{array}$ & $\begin{array}{l}\text { Part } \\
\text { used }\end{array}$ & Quantity \\
\hline 1 & Shunti & $\begin{array}{l}\text { Zingiber } \\
\text { officinale.L }\end{array}$ & Rhizome & $25 \mathrm{~g}$ \\
\hline 2 & Haridra & $\begin{array}{l}\text { Curcuma } \\
\text { longa.L }\end{array}$ & Rhizome & $25 \mathrm{~g}$ \\
\hline 3 & Maricha & $\begin{array}{l}\text { Piper } \\
\text { nigrum.L }\end{array}$ & Fruit & $25 \mathrm{~g}$ \\
\hline 4 & Lashuna & $\begin{array}{l}\text { Allium } \\
\text { sativum.L }\end{array}$ & Bulb & $25 \mathrm{~g}$ \\
\hline 5 & Jala & Water & - & $100 \mathrm{ml}$ \\
\hline
\end{tabular}

\section{Method of preparation of Shuntyadi balm}

All the ingredients were taken $200 \mathrm{~g}$ each and converted into coarse powder except lashuna which was added in the form of kalka. Kwatha was prepared by adding 12 litre of water (16 times) and reduced to 400 $\mathrm{ml}\left(1 / 4^{\text {th }}\right)$. Kwatha was filtered through clean cloth and re boiled till it attains semisolid consistency i.e., ghanasara. The obtained ghanasara was dried under sunlight and powdered. To this powder of ghanasara, menthol, methyl salicylate and camphor were added as excipients. Sikta taila was prepared using madhuchista and tila taila in ratio of 1:6. Sikta taila was added to the mixture of ghanasara, menthol, methyl salicylate and camphor. 3 trails of balm were prepared by varying the percentage of additives. Among these three trails, the 3 rd trial was feasible considering the consistency. Total end product obtained was $480 \mathrm{~g}$ and was packed into 40 bottles each of $12 \mathrm{~g}$. A total of 15 patients were administered with shuntyadi balm for application who have shirashula.

Table 2: Showing the ingredients with proportion 3rd trial

\begin{tabular}{|r|l|l|}
\hline Sl.no & Ingredient & Quantity \\
\hline 1 & Extract of drug & $90 \mathrm{~g}$ \\
\hline 2 & Menthol & $9 \mathrm{~g}(10 \%)$ \\
\hline 3 & Methyl salicylate & $9 \mathrm{ml}(10 \%)$ \\
\hline 4 & Camphor & $9 \mathrm{~g}(10 \%)$ \\
\hline 5 & Bee wax & $14 \mathrm{~g}$ \\
\hline 6 & Siktha taila & $50 \mathrm{ml}$ \\
\hline
\end{tabular}

\section{Selection of patients}

The study was conducted in 34 clinically diagnosed patients of shirashula out of which 4 patients discontinued the treatment and the rest 30 patients completed the treatment. The patients were selected from the OPD \& IPD of SDM College of Ayurveda and Hospital, Hassan as per the selection criteria. All the patients were randomly divided into two groups.

\section{Selection criteria}

Individuals of either sex within the age group of 20 - 50 years having the history of shirashula were selected randomly.

\section{Exclusion criteria}

- Individuals below 20 years and above 50 years of age.

- Patients associated with other major systemic or psychiatric diseases.

- Headache due to other major causes like Migraine, Trigeminal neuralgia, Intracranial space occupying lesions and other systemic diseases such as Hypertension, Refractive errors etc.

- Patients having increased Intracranial Tension due to any reason.

Symptom Rating Scale for shirashula (headache) developed by Prof. A.K. Sharma et.al.

\begin{tabular}{|l|l|l|l|l|} 
SI. & Symptoms & Grades & No. & \% \\
\hline 1 & Absent & - & 0 & 0 \\
\hline 2 & Mild & + & 1 & $25 \%$ \\
\hline 3 & Moderate & ++ & 2 & $50 \%$ \\
\hline 4 & Severe & +++ & 3 & $75 \%$ \\
\hline 5 & Agonizing & ++++ & 4 & $100 \%$ \\
\hline
\end{tabular}

\section{Observations ans Results}

To check the efficacy of both the dosage forms i.e., lepa and balm in shirashula, preliminary clinical study was conducted with permission of institutional ethical committee (SDM/IEC/73/2019). Prepared shuntyadi yoga in the form of pellets and balm administered to 15 patients having shirashoola in each group for external application on forehead.

\section{Result of shirashulahara effect of vati form}

Out of 15 patients 14 had got relief from shirashula after its application. Among 14, 10 got complete relief and 4 got moderate relief. 1 among 15 
did not got relief (h/o sinusitis). 2 among 15 complained of slight burning sensation.

\section{Result of shirashulahara effect of balm form}

Out of 15 patients 14 had got relief from head ache after its application. All 14 got complete relief. 1 among 15 did not got relief (h/o sinusitis). No complaint of burning sensation.

\section{Discussion}

Shirashula is one of the common symptoms in many diseases and shirolepa is one of the sthanika chikitsa. Lepa pacifies the provoked local dosha by prahladana, shodhana, sopha harana. Shuntyadi yoga is one of the traditionally practiced formulation for treatment of shirashula. To make the formulation more patient compliance and to carry forward the traditional formulation it was modified into neo formulation.

All the drugs used in the preparation were proved for their analgesic activity by recent studies $(5,6,7,8,9,10,11,12)$. Maricha and shunti are proved for their bioavailability enhancing property (13). Shunti is proved for its dermal absorption enhancing property (14).

\section{Conclusion}

Lepa and balm were administered for 15 patients each and both the formulations have shown promising result in shirashula. In shuntyadi vati group, 93\% patients got relief among which $71.43 \%$ patients got complete relief and $28.57 \%$ patients got moderate relief. In shuntyadi balm group, 93\% patients got complete relief. In shuntyadi vati group, $13.33 \%$ patients complain of burning sensation which was absent in shuntyadi balm group. So, considering result and the patient compliance, balm said to be more beneficial to the patient.

\section{Source of support \& Acknowledgement}

Rajiv Gandhi University of Health Sciences, Bengaluru, Karnataka. Short term research grant for undergraduate students with Project NameComparative Analgesic Effect Of Traditional Formulation Shuntyadi Yoga Lepa And Its Neo Formulation as Balm on Shirashula \& Project codeUGAYU045.

\section{References}

1. Dhote M, Rathi B, Rajput DS, Dongre R. A review on Lepa Kalpana: An inherent topical formulations described in Sharangadhar Samhita. Journal of Indian System of Medicine. 2019 Apr 1;7(2):75.
2. Mukesh Kumar, Sreeja Sukusen, C. Sindhu, Rajan Nelson Munzni, Systemic Review Of Shirashoola (Headache) And Role Of Jaladhara (Pouring Of A Water On The Forehead) In Vataj Shirashoola, International Journal of Innovative Pharmaceutical Sciences and Research, 2019; 7 (10):14-24.

3. Gaurav Gaur et al, Shirodhara In The Management Of Vatika Shirashoola. International Ayurvedic Medical Journal, 2018 Mar;6(3):679-683.

4. Anuradha: shirodhara in the management of vatika shirashoola with special reference to chronic daily headache: A review International Journal of Applied Ayurved Research, 2017;3(1):56-60.

5. Suresh N Hakkandi: A Comparative Study to Evaluate the Efficacy of ksheerabala Taila Nasya and Sahachara Taila Nasyain Vatika Shirahshoola w. s. r. to Tension-Headache; ayurpub; IV(1): 1154-1161

6. Khare, C.P. Indian Medicinal Plants, Springer Science, Business Media, LLC.,233, Spring Street, New York, NY 10013, USA; 2007. 733-34p.

7. Khare, C.P. Indian Medicinal Plants, Springer Science, Business Media, LLC.,233, Spring Street, New York, NY 10013, USA; 2007. 492p.

8. Khare, C.P. Indian Medicinal Plants, Springer Science, Business Media, LLC.,233, Spring Street, New York, NY 10013, USA;2007.187-88p.

9. Khare, C.P. Indian Medicinal Plants, Springer Science, Business Media, LLC.,233, Spring Street, New York, NY 10013, USA; 2007. 34-35p.

10. Rayati F, Hajmanouchehri F, Najafi E. Comparison of anti-inflammatory and analgesic effects of Ginger powder and Ibuprofen in postsurgical pain model: A randomized, double-blind, case-control clinical trial. Dental research journal. 2017 Jan;14(1):1.

11. Terry R, Posadzki P, Watson LK, Ernst E. The use of ginger (Zingiber officinale) for the treatment of pain: a systematic review of clinical trials. Pain medicine. 2011 Dec 1;12(12):1808-18.

12. Jogdand S, Bhattacharjee J. Evaluation of analgesic activity of turmeric (Curcuma longa Linn.) in Wister rats. Int J Basic Clin Pharmacol. 2017 Mar;6:568-71.

13. Tiwari Ranjana, Tripathi V.D, Therapeutic Effect Of Haridra (Curcuma Longa Linn.) In General, And Oral Health- A Review:AYUSHDHARA, 2014;1(2):40-43.

14. Muhammad F, Wiley J, Riviere JE. Influence of some plant extracts on the transdermal absorption and penetration of marker penetrants. Cutaneous and ocular toxicology. 2017 Jan 2;36(1):60-6. 


\section{Photos of Shuntyadi vati preparation}

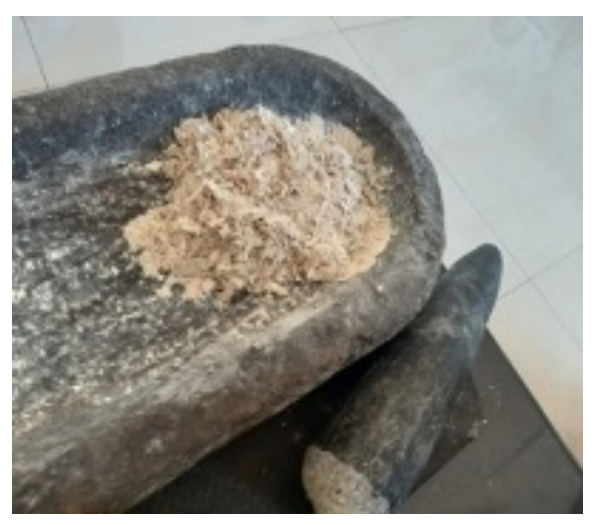

Photo 1.Powdering of raw drugs

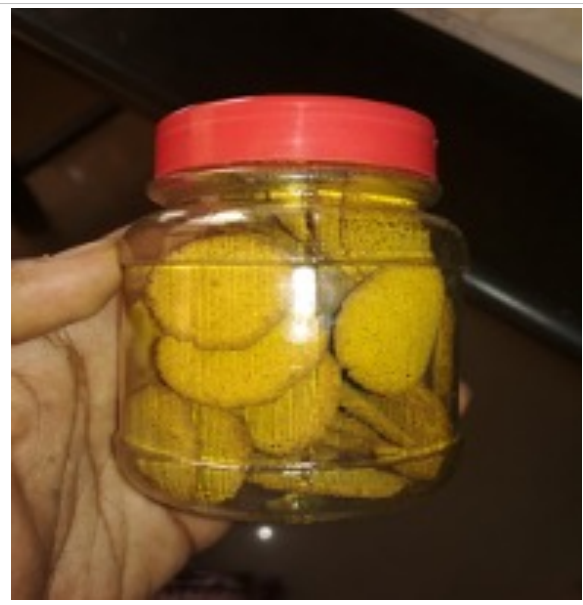

Photo 4. Shuntyadi yoga in vati form after drying it completely.

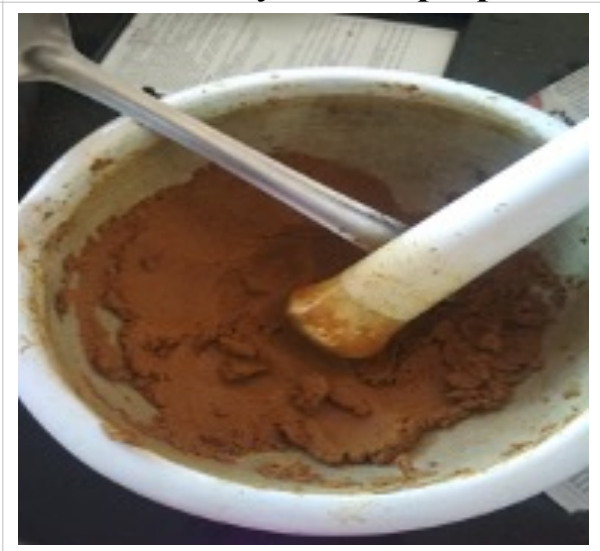

Photo 2.Bhavana with jala

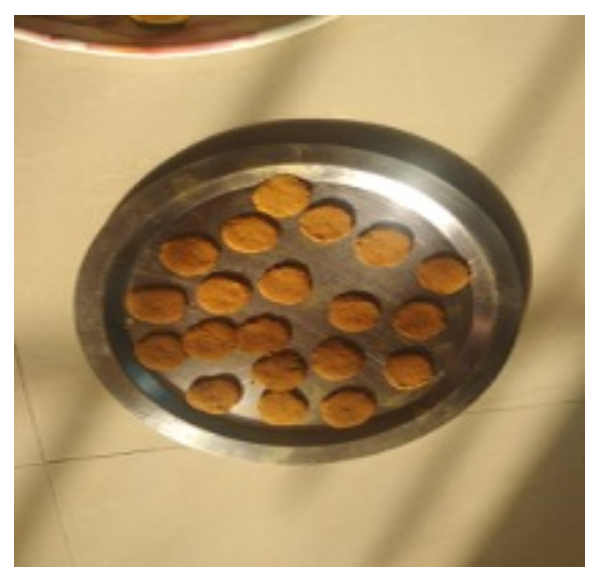

Photo 5. Drying under sunlight

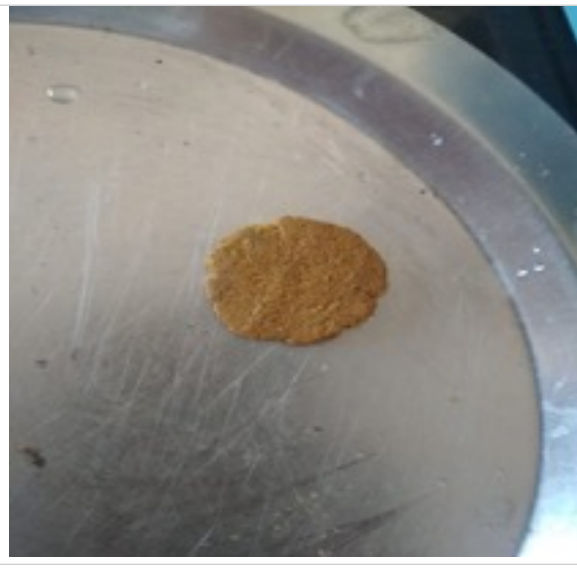

Photo 3. Subhavitha mishrana was made in to vati form.

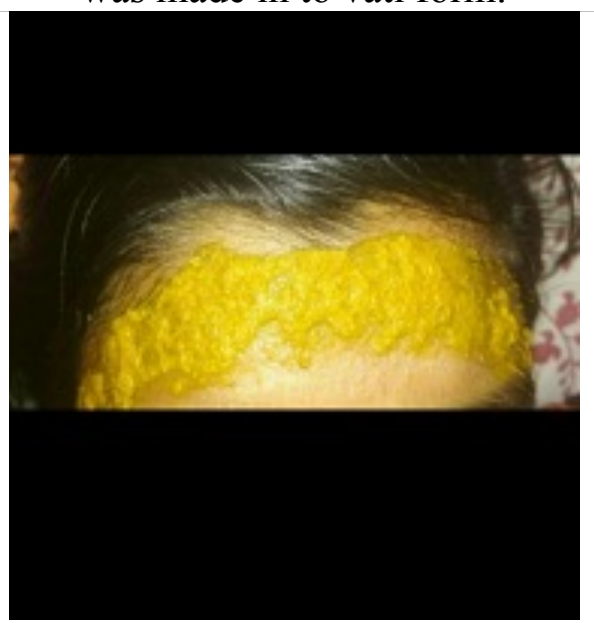

Photo 6. Application of lepa

\section{Preparation of Shuntyadi balm}

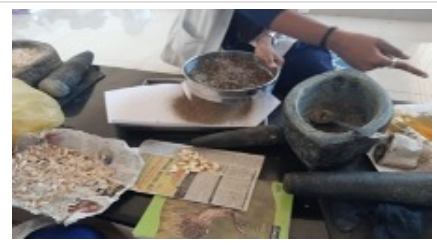

Photo 1. Powdering of raw drugs in to coarse powder

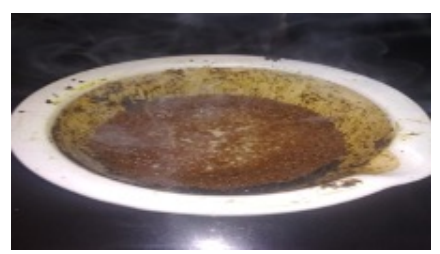

Photo 5. Ghanasara added with sikta and taila

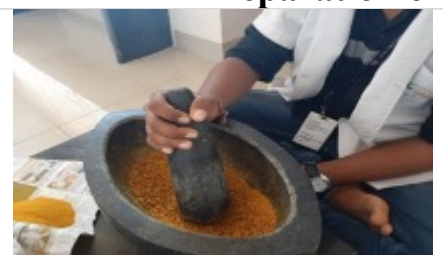

Photo 2. Powdering of haridra

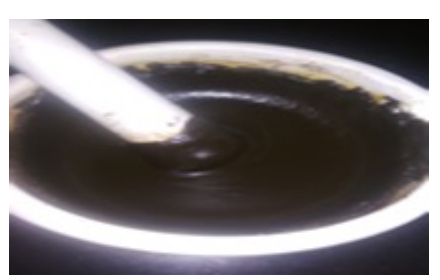

Photo 6. Menthol, methyl salicylate and camphor was added

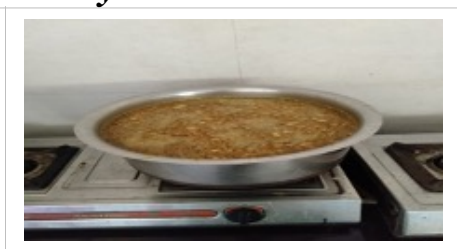

Photo 3. Kwatha Preparation

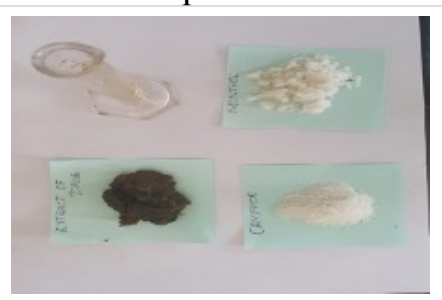

Photo 7. Ingredients of shuntyadi balm

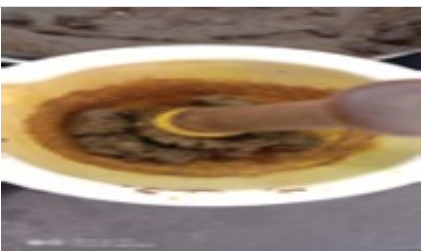

Photo 4. Ghanasara Obtained

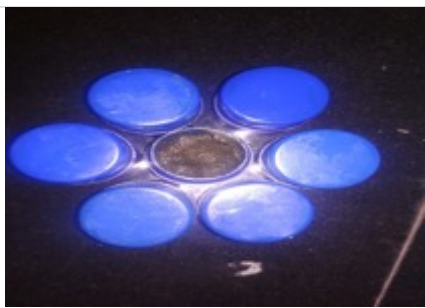

Photo 8 . Shuntyadi yoga in balm form 